Jurnal Hukum Mimbar Justitia

Fakultas Hukum Universitas Suryakancana

Vol. 6 No. 2 - Desember 2020, hlm. 173-189.

ISSN: 2477-5681 (Cetak), ISSN: 2580-0906 (Online)

Open Access at: https://jurnal.unsur.ac.id/jmi

\title{
URGENSI PENDIDIKAN ANTIKORUPSI TERHADAP PENCEGAHAN KORUPSI DALAM PENDIDIKAN DASAR
}

\author{
Gregorius Widiartana \\ Universitas Atma Jaya Yogyakarta \\ Email: g.widiartana@gmail.com \\ dan \\ Vincentius Patria Setyawan \\ Universitas Atma Jaya Yogyakarta \\ Email: vincentpatria@gmail.com
}

Masuk: September 2020 Penerimaan: Oktober 2020 Publikasi: Desember 2020

\begin{abstract}
ABSTRAK
Pemberantasan korupsi di Indonesia masih belum optimal untuk dilaksanakan dan masih mengutamakan pada penindakan/represif terhadap perkara korupsi yang telah terjadi. Pelaksanaan upaya yang demikian ini kurang efektif di dalam memberantas korupsi oleh karena korupsi telah mengakar dalam budaya hukum masyarakat. Salah satu cara yang dapat dilaksanakan di dalam upaya pemberantasan korupsi adalah dengan melakukan pencegahan korupsi yang dapat dilakukan dengan pemberian pendidikan antikorupsi, khususnya bagi pelajar di tingkat pendidikan dasar. Pendidikan dasar menjadi fokus pemberian pendidikan antikorupsi sebab di tingkatan inilah pembentukan karakter seseorang, dan pendidikan antikorupsi sejatinya adalah pendidikan karakter.
\end{abstract}

Kata Kunci : Pencegahan Korupsi, Tindak Pidana Korupsi, Pendidikan Antikorupsi

\begin{abstract}
Corruption eradication in Indonesia is still not optimal and still prioritizes repressive actions against corruption cases that have occurred. The implementation of such efforts is ineffective in eradicating corruption because corruption has taken root in the legal culture of society. One of the ways that can be implemented in efforts to eradicate corruption is to prevent corruption which can be done by providing anticorruption education, especially for students at the primary education level. Primary education is the focus of providing anti-corruption education because it is at this level that the character building of a person, and anti-corruption education is actually character education.
\end{abstract}

Keywords : Corruption Prevention, Corruption Crime, Anti-Corruption Education. 
Jurnal Hukum Mimbar Justitia

Fakultas Hukum Universitas Suryakancana

Vol. 6 No. 2 - Desember 2020, hlm. 173-189.

ISSN: 2477-5681 (Cetak), ISSN: 2580-0906 (Online)

Open Access at: https://jurnal.unsur.ac.id/jmj

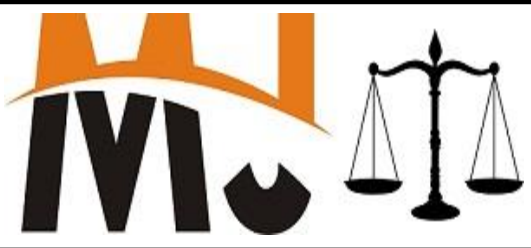

I. PENDAHULUAN

Membahas

mengenai

pemberantasan korupsi sering

dikaitkan dengan pemberian sanksi

pidana yang seberat-beratnya yang

sering kali dianggap sebagai upaya yang

paling ampuh. Pandangan yang

demikian ini sejalan dengan

penggunaan tujuan pidana

sebagaimana yang berkembang dalam

aliran klasikyakni teori absolut/mutlak.

Teori absolut/mutlak lahir dalam aliran

klasik hukum pidana. Berdasarkan

teori/madzhab ini pembalasan adalah ${ }^{1}$

legitimasi pemidanaan. Jika

dihubungkan dengan teori tersebut,

maka pemberantasan korupsi ditujukan

untuk melakukan pembalasan terhadap

pelaku korupsi, dan bentuk

pembalasannya dengan menjatuhkan

sanksi pidana yang seberat-beratnya

kepada koruptor.

Pandangan yang menitikberatkan pemberantasan korupsi dengan teori absolut dengan penggunaan hukum pidana dianggap sebagai sebuah

1 Eddy O.S. Hiariej, 2014, Prinpsip-Prinisip Hukum Pidana, Cahaya Atma Pustaka, Yogyakarta, hlm. 33. langkah yang paling tepat di dalam memberantas korupsi. Sebagaimana kita ketahui bersama, negara kita telah memiliki berbagai instrumen hukum guna memberantas korupsi yang berupa aturan perundangundangan. Selain itu, kita juga memiliki aparat penegak hukum yang berkwajiban untuk melaksanakan aturan-aturan tersebut untuk melaksanakan tugas pemberantasan korupsi, mulai dari tahap pemeriksaan pendahuluan yaitu penyelidikan dan penyidikan, sampai dengan tahap pemeriksaan di persidangan melalui lembaga pengadilan. Bahkan kita memiliki lemabaga independen yakni Komisi Pemberantasan Korupsi (KPK).

Namun kenyataan yang terjadi di masa ini, korupsi tidak cenderung mengalami penurunan kendati telah dibentuk peraturan perundangundangan yang mengatur pemberantasannya. Ironisnya, fakta menunjukkan bahwa aparat penegak hukum justru menjadi pihak yang ikut dan turut serta menumbuhkembangkan korupsi di 
negeri ini. Transaksional perkara adalah potret penegakan hukum yang sangat jauh dari penegakan hukum yang bersih, jujur dan adil.

Pemberantasan korupsi idealnya dimulai dari aparat penegak hukum, seperti sebuah idiom yang mengatakan. "as long as the dirty broom is not celande everything talk about law is empty". Hal tersebut bermakna bahwa pemberantasan korupsi hendaknya dimulai dari keteladanan dari aparat penegak hukum. Secara tidak langsung dengan memberikan keteladanan, maka kepercayaan/trust masyarakat kepada penegakan hukum akan tumbuh.

\section{Fenomena}

tersebut menunjukkan, pemberantasan korupsi dengan menegakkan sanksi pidana belum lah optimal dalam memberantas korupsi. Jika kita tarik benang merah dengan teori penegak hukum sebagaimana dikemukakan oleh L. Friedman, ${ }^{2}$ penegakan hukum akan memiliki arah dan tujuan yang pasti

2 Slamet Tri Wahyudi, 2012, Problematika Penerapan Pidana Mati dalam Konteks Penegakan Hukum di Indonesia, Jurnal Hukum dan Peradilan, Volume 1, Nomor 2, $\mathrm{hlm} .217$. serta dapat dilaksanakan secara tepat jika terdapat sinergi antara elemenelemen di dalamnya yakni aspeksubstansi, aspek struktur, dan aspek budata. Pemberantasan korupsi sudah dilengkapi dengan sekian banyak aturan perundang-undangan yang mendukung, akan tetapi belum ditunjang dengan aparat penegak hukum yang berkomitmen kuat untuk memberantas korupsi, serta budaya hukum masyarakat belum menunjukkan dukungannya untuk memberantas korupsi. Budaya hukum dapat terlihat bahwa kecenderungan masyarakat, khususnya koruptor cenderung untuk membuat kejahatan baru yakni melakukan suap maupun gratifikasi untuk menghindar dari pertanggungjawaban pidana setelah melakukan korupsi.

Berdasarkan statistik korupsi yang disusun oleh KPK, pada tahun 2018 menunjukkan bahwa prosentase penyuapan cukup tinggi dari sekian banyak kasus korupsi yang terjadi di negeri ini, yakni mencapai angka $60 \%$. Pelaku dari penyuapan tersebut didominasi oleh sektor swasta dan 
Vol. 6 No. 2 - Desember 2020

sektor publik/pemerintah yang
keseluruhannya mencapai $80 \% .^{3}$
Melihat data tersebut, maka dapat
dikatakan bahwa upaya pemberantasan
korupsi dengan penegakan hukum
pidana terhadap pelaku korupsi

belumlah mencapai hasil yang optimal.

Perlu dilakukan upaya yang lebih optimal daripada melakukan sebuah upaya represif dalam memberantas korupsi, yakni dengan melakukan upaya preventif yang sering dikenal dengan pencegahan korupsi. Pencegahan korupsi salah satunya dapat dilakukan dengan memberikan pendidikan antikorupsi kepada siswa pada jenjang pendidikan formal.

KPK telah memberikan nilai-nilai yang harus diimplementasikan di dalam memberikan pendidikan antikorupsi bagi masyarakat. Nilai-nilai antikorupsi

3 Kementerian PPN/Bappenas, 2018, Pencegahan dan Pemberantasan Korupsi dalam Konteks Perencanaan Pembangunan: Materi Perencanaan Pembangunan Nasional, disampaikan pada International Bussines Integrity Conference yang diselenggarakan pada 4 Desember 2018, https://www.kpk.go.id/images/Integrito/20 18/MateriHAKORDIA2018/Pencegahan-danPemberantasan-Korupsi-dalam-KonteksPerencanaan-Pembangunan---MenteriPerencanaan-pembangunan-Nasional.pdf, diakses pada 27 September 2020, Pukul 06:37 WIB. tersebut dijabarkan menjadi 3 (tiga) bagian yakni : inti, etos kerja, dan sikap. Bagian inti terdiri dari sikap jujur, disiplin, dan tanggungjawab, sedangkan etos kerja terdiri dari kerja keras, mandiri dan sederhana. Serta sikapsikap yang harus dikembangkan dalam membentuk perilaku antikorupsi yakni adil, berani, dan peduli.

Pendidikan antikorupsi di tingkat pendidikan dasar sangat diperlukan guna mengoptimalkan pemberantasan korupsi, meliputi perbaikan sistem, perbaikan kelembagaan, serta penegakan hukum. Pendidikan antikorupsi adalah upaya perbaikan budaya politik dalam jalur pendidikan untuk melakukan perubahan

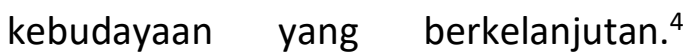
Pendidikan antikorupsi khususnya di jenjang pendidikan dasar (Sekolah Dasar dan Sekolah Menengah Pertama) adalah sangat penting oleh karena pada tingkat pendidikan dasar tersebut, karakter anak dibentuk. Salah satu tujuan pembentukan karakter adalah

4 Karlina Helmanita dan Sukron Kamil, Pendidikan Antikorupsi di Perguruan Tinggi, CSRC UIN Syarif Hidayatullah, Jakarta, hlm. viii. 
untuk membentuk kepribadian peserta

didik yang berakhlak mulia dan menghindari perilaku korupsi.

Artikel ini akan membahas terkait dengan urgensi pendidikan antikorupsi terhadap pencegahan korupsi di Indonesia, yang menitikberatkan tentang peran pendidikan antikorupsi dan penanaman nilai-nilai antikorupsi dalam rangka pencegahan korupsi di Indonesia.

\section{METODE PENELITIAN}

Penulisan artikel ini menggunakan metode penulisan berjenis normatif ${ }^{5}$ yang memposisikanhukum sebagai konstruksi sistem norma mengenai asas-asas, putusan hakim, perjanjian/perikatan, serta doktrin/ajaran). Bahan hukum yang dipakai di dalam penulisan artikel ini adalah berupa bahan hukum primer serta bahan

hukum sekunder. ${ }^{6}$ Penggunaan bahan hukum disesuaikanrelevansinya dengan permasalahan yang dihadapi yakni mengenai pendidikan khsusunya pendidikan karakter dan mengenai pemebantasan dan pencegahan korupsi. Pengumpulan bahan hukum dalam artikel ini dilakukan dengan studi pustaka $^{7}$ yang dilaksanakan dengan mempelajari bahan hukum untuk menjawab permasalahan/issue hukum yang dibahas yakni tentang pendidikan antikorupsi dan pencegahan korupsi.

\section{PEMBAHASAN}

Penegakan hukum (pidana) jika pandang sebagai suatu pembentukan kebijakan maka pada hakikatnya merupakan penerapan kebijakan melalui beberapa tahap yaitu terdiri dari: ${ }^{8}$

A. Tahap Pembentukan yaitu tahap pembentukan peraturan perundang-undangan yang

6 Peter Mahmud Marzuki, 2005, Penelitian Hukum: Edisi Revisi, Kencana Prenada Media Group, Jakarta, hlm. 141-168.

7 Mukti Fajar dan Yulianto Achmad, Op.cit, hlm. 160.

8 Muladi, 1995, Kapita Selekta Sistem Peradilan Pidana, Badan Penerbit Universitas Diponegoro, Semarang, hIm. 1314. 


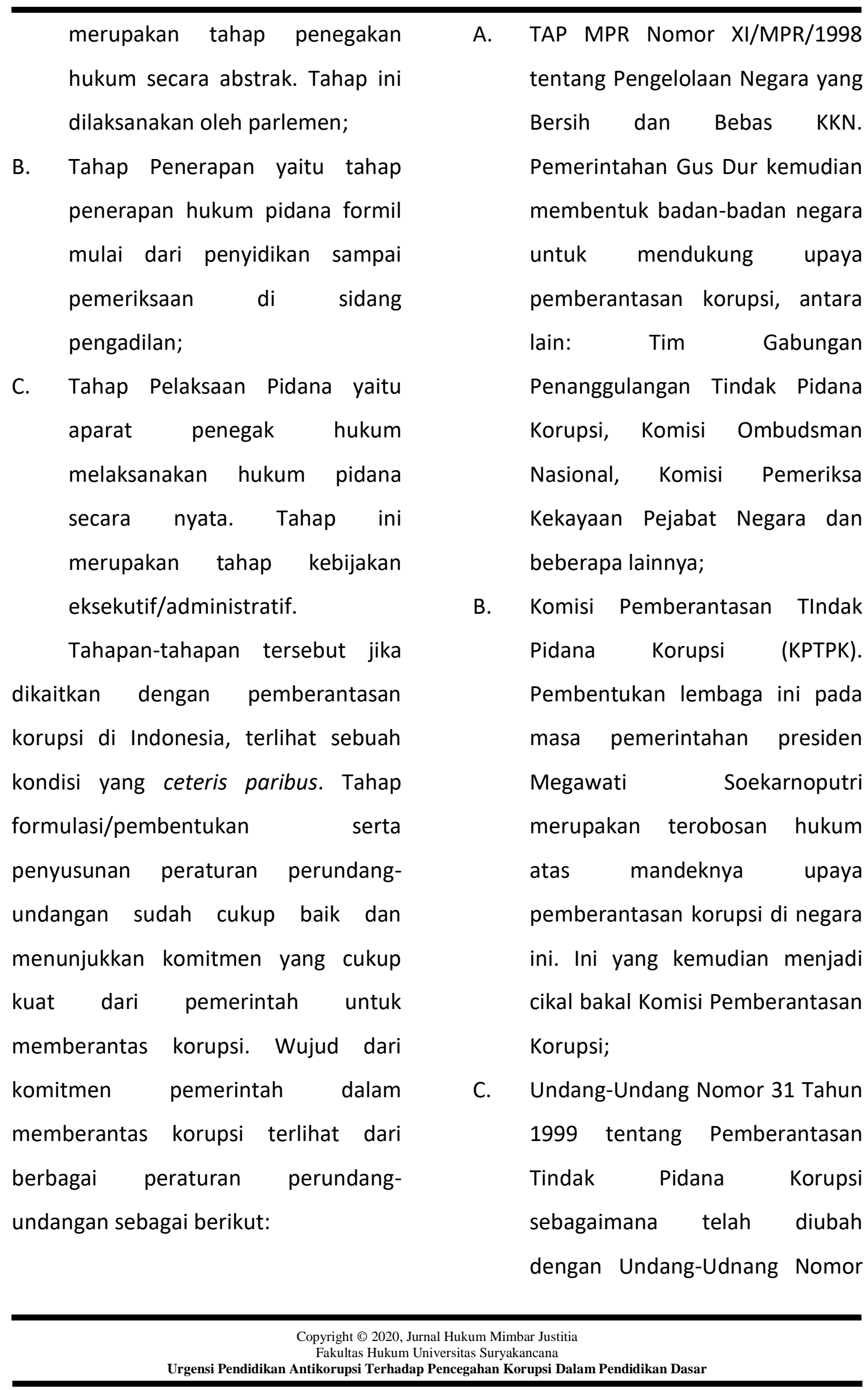




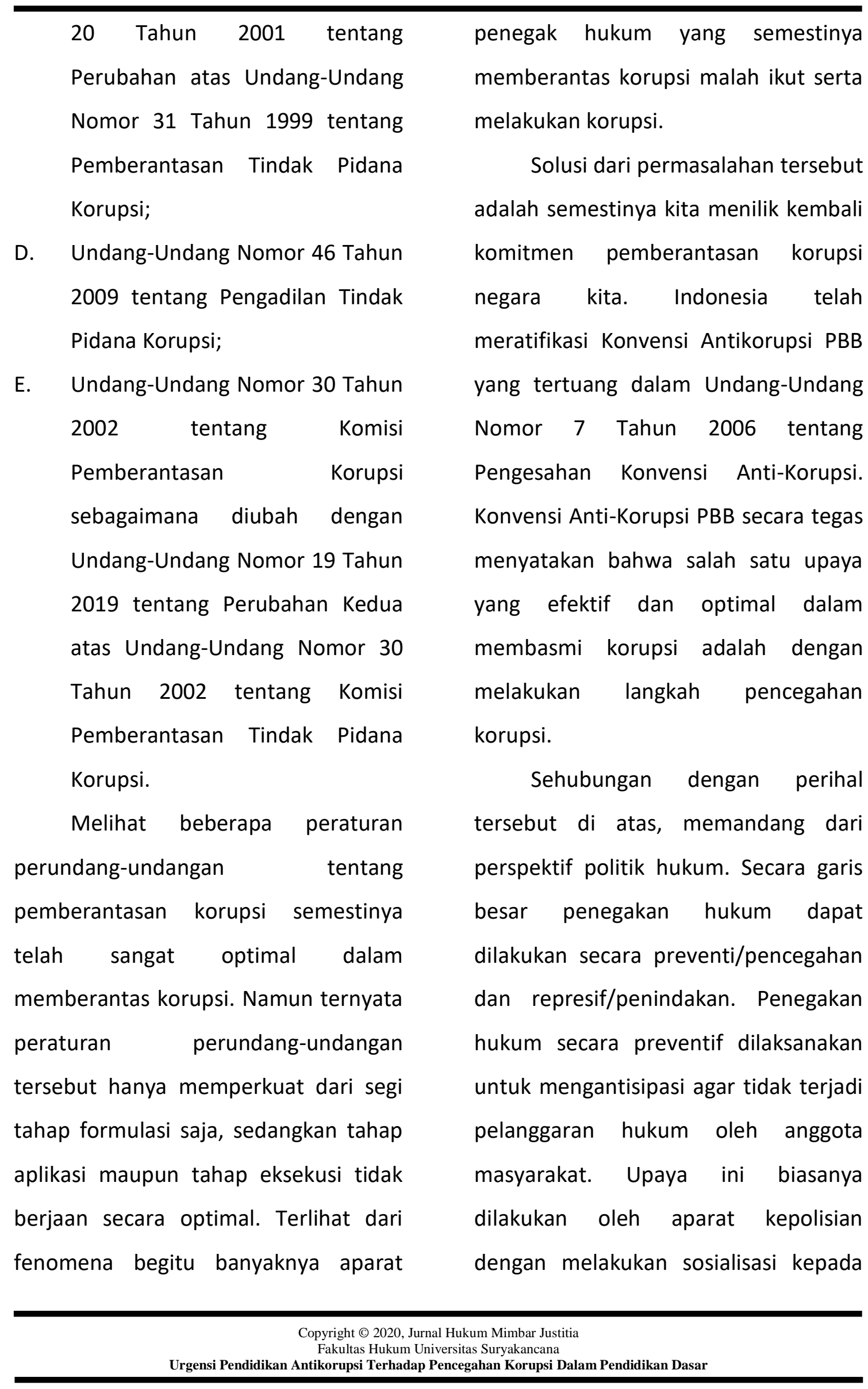


masyarakat, namun ada kalanya pengadilan juga melakukan upaya ini dalam mekanisme persidangan. ${ }^{9}$

Prioritas penegakan hukum adalah pertama-tama dilakukan upaya hukum preventif terlebih dahulu, dan jika tidak optimal/masih terjadi pelanggaran hukum maka diperlukan penegakan hukum secara represif. Penegakan hukum secara represif dilakukan oleh aparat penegak hukum mulai dari kepolisian selaku penyidik sampai dengan proses persidangan serta pembinaan yang dilakukan oleh lembaga pemasyarakatan. ${ }^{10}$

Berdasarkan politik hukum pidana, apabila dikaitkan dengan pemberantasan korupsi maka upaya yang seharusnya dilakukan untuk memberantas korupsi adalah diawali dengan upaya preventif terlebih dahulu. Apabila upaya

9 Bambang Poernomo, et al, 1978, Sumbangan Pendidikan Hukum dalam Peningkatan Pelaksanaan Tugas Penegakan Hukum, Seminar Hukum, Penerbit Seksi Hukum Pidana dan Kriminologi Fakultas Hukum Universitas Gajah Mada, Yogyakarta, hlm. 163 dalam Teguh Prasetyo dan Abdul Halim Barkatullah, 2012, Politik Hukum Pidana: Kajian Kebijakan Kriminalisasi dan Dekriminalisasi, Pustaka Pelajar, Yogyakarta, hlm. 111-112.

10 Loc.cit. preventif/pencegahan korupsi tidak optimal dalam memberantas korupsi, barulah menggunakan upaya represif yakni menindak pelaku korupsi yakni dengan menggunakan sanksi pidana, dimulai dari tahap penyidikan, penuntutan, pemeriksaan di pengadilan, menjatuhkan sanksi pidana dengan putusan hakim dan pelaksanaan sanksi tersebut di Lembaga Pemasyarakatan.

Ironisnya, selama ini langkah pemberantasan korupsi selama ini adalah telah salah orientasi. Semestinya dimulai dengan upaya preventif terlebih dahulu, dan barulah jika belum mampu mengatasi korupsi dilanjutkan dengan upaya represif. Kesalahan orientasi ini dilatarbelakangi oleh pandangan yang keliru terhadap pemberantasan korupsi, oleh karena sebagai kejahatan luar biasa. Pandangan yang muncul selama ini adalah jika dengan menjatuhkan sanksi yang seberat-beratnya kepada koruptor akan menimbulkan efek jera bagi koruptor. Namun yang terjadi sebaliknya, sanksi tersebut tidak didukung dengan aplikasi yang baik 
oleh karena aparat penegak hukum lebih cenderung kompromis dengan koruptor. Semestinya pemberantasan korupsi ditekankan pada upaya preventif, yakni pencegahan korupsi yang salah satunya bisa dilaksanakan dengan menanamkan nilai-nilai antikorupsi kepada pelajar/peserta didik dengan mengajarkan pendidikan antikorupsi yang merupakan pendidikan karakter dengan menanamkan nilai-nilai antikorupsi.

Berbicara mengenai pendidikan antikorupsi, ternyata belum banyak kalangan masyarakat yang mengetahui mengenai pendidikan antikorupsi. Fenomena tersebut menyebabkan pendidikan antikorupsi belum dapat diimpelementasikan secara optimal sebagai upaya pencegahan korupsi. Untuk dapat menerapkan pendidikan antikorupsi secara optimal, perlu kiranya kita ketahui permasalahanpermasalahan yang selama ini muncul dalam implementasi pendidikan antikorupsi.

Beberapa permasalahan yang muncul dalam implementasi pendidikan antikorupsi saat ini adalah sebagai berikut: ${ }^{11}$

A. Peserta didik belum mendapatkan pemahaman yang cukup tentang antikorupsi. Maka mereka perlu diperkenalkan terlebih dahulu dengan niali-nilai konkret yang dapat menentang korupsi;

B. Peserta didik/siswa belum mendapatkan keteladanan yang cukup dari lingkungan pergaulan sehari-hari (baik orang tua, guru, dan media). Penanaman nilai/internalisasi nilai atau budi pekerti akan sangat optimal jika peserta didik diberikan keteladanan;

C. Terdapat persiangan yang kurang sehat antara peserta didik/siswa terutama di bidang prestasi belajar. Perlu ditanamkan kepada siswa menjadi anak cerdas itu memang perlu namun tetap harus saling hormatmenghormati, menghargai, sederhana dan tidak tinggi hati. Selain itu apresiasi pihak sekolah

11 Eko Handoyo, Op.cit, hlm. 10-11 
perlu diberikan, tidak hanya bagi

siswa yang berprestasi secara akademis/non akademis, akant tetapi bagi siswa yang berpekerti baik;

D. Sekolah belum sepenuhnya melaksanakan aturan secara konsekuen. Maka seharusnya aturan sekolah tidak dibuat sepihak oleh sekolah, namun dalam pembentukannya dimintakan pendapat kepada orang tua dan kepada siswa. Sehingga dalam implementasinya, siswa secara tidak langsung akan terbebani jika melanggar komitmen yang telah disepakati bersama;

E. Pembelajaran disekolah yang masih terpaku pada pola belajar yang menekankan kognisi semata. Maka sebaiknya perlu dikembangkan pembelajaran dengan metode yang beragam dengan harapan mudah diserap dan dipahami siswa tanpa mengurangi esensi materi yang disampaikan.
Secara garis besar pendidikan antikorupsi adalah ${ }^{12}$ pendidikan koreksi kultur yang memiliki tujuan untuk memperkenalkan cara berpikir dan penanaman nilai-nilai baru kepada peserta didik. Merebaknya korupsi di tanah air menjadikan korupsi seakan sudah membudaya dan menjadi hal yang biasa. Pendidikan antikorupsi memegang peranan penting untuk mengubah pola pikir anak didik dengan menanamkan nilai-nilai antikorupsi, untuk menciptakan persepsi peserta didik bahwa korupsi adalah perbuatan tercela dan harus dihindari.

Pendidikan antikorupsi juga dapat dimaknai sebagai usaha yang terstruktur dan sistematis untuk memberikan pengetahuan, nilai-nilai serta sikap guna membekali peserta didik untuk menjadi agen penggerak pencegahan korupsi serta menghilangkan potensi tumbuh dan berkembangnya korupsi. Tujuan akhir pendidikan antikorupsi bukanlah hanya mereka memahami konsep pendidikan antikorupsi, akan tetapi mereka

12 Totok Suyanto, 2005, Pendidikan Anti Korupsi dan Pengembangan Budaya Sekolah, Nomor 23, Edisi XIII, JPIS, hlm. 43. 
mampu untuk mengatasi segala pengaruh dari lingkungan sekitar/dunia pergaulan yang berpotensi dilakukannya perilaku koruptif.

Jika dikaitkan dengan tujuan pendidikan, pendidikan antikorupsi bertujuan untuk: ${ }^{13}$

A. Membentuk pemaknaan tentang berbagai jenis korupsi dan dimensi-dimensinya;

B. Perubahan paradigma dan sikap terhadap korupsi;

C. Mempersiapkan kemampuan untuk menghalau terjadinya korupsi.

Berdasarkan tujuan-tujuan tersebut, dapat dipahami bahwa pendidikan antikorupsi diimplementasikan dengan memperhatikan 3 (tiga) aspek penting dalam penyelenggaraan pendidikan yakni: aspek kognitif, aspek afektif, dan aspek psikomotorik. Aspek kognitif ditanamkan dengan memberikan informasi tentang konsep pendidikan antikorupsi berikut tujuan-tujuan dilaksanakannya pendidikan antikorupsi. Sedangkan aspek afektif

13 Eko Handoyo, Op.cit, hlm. 43-44. menekankan pada implementasi konsep pendidikan antikorupsi yang dikonkretkan pada sikap-sikap peserta didik yang sesuai dengan nilai-nilai antikorupsi sebagaimana telah diajarkan secara teoritik dalan aspek kognitif. Implementasi pendidikan antikorupsi dilengkapi pula dengan aspek psikomotorik yang menekankan pada harmonisasi antara konsep serta implementasi pendidikan antikorupsi dalam sikap antikorupsi, dengan kurikulum pembelajaran yang digunakan sehingga pendidikan antikorupsi benar-benar dapat direalisasikan secara selaras dan seimbang dalam proses pendidikan dan pengajaran.

Pendidikan antikorupsi perlu untuk diselenggarakan dalam pendidikan formal maupun pendidikan informal. Namun, diantara keduanya pendidikan formal dianggap lebih optimal oleh karena otoritas dan kultur yang dimilikinya. ${ }^{14}$ Implementasi pendidikan antikorupsi pada pendidikan formal dilakukan dengan terlebih dahulu menanamkan nilai-nilai

14 Ibid, hlm. 44. 
antikorupsi yang terdiri dari: Nilai-nilai kejujuran, keterbukaan, tanggung jawab, kerja keras, keberanian, kesederhanaan, keadilan, kedisiplinan dan komitmen. Nilai-nilai tersebut dapat terrencana, terrealisasi, dan terawasi dengan baik pada jalur pendidikan formal.

Sejalan dengan hal tersebut, merujuk pada tujuan pendidikan dalam Sistem Pendidikan Nasional yakni untuk mengembangkan potensi peserta didik agar menjadi manusia yang beriman dan bertakwa kepada Tuhan Yang Maha Esa, berakhlak mulia, sehat, berilmu, cakap, kreatif, mandiri, dan menjadi warga negara yang demokratis serta mendiri. ${ }^{15}$ Tujuan pendidikan dalam Sistem Pendidikan Nasional tersebut jika dilihat dari rumusannya terlihat bahwa tujuan pendidikan tidak hanya menakankan pada aspek pengetahuan/ilmu semata untuk membentuk insan yang cerdas, akan tetapi juga diarahkan untuk membentuk akhlak, serta budi yang luhur. Terdapat benang merah antara

15 Pasal 3 Undang-Undang Nomor 20 Tahun 2003 tentang Sistem Pendidikan Nasional. tujuan pendidikan antikorupsi dan tujuan pendidikan secara garis besar.

Penyelenggaraan pendidikan antikorupsi telah diamanatkan di dalam Pasal 13 huruf c Undang-Undang Nomor 30 Tahun 2002 tentang Komisi Pemberantasan Korupsi sebagaimana telah diubah dalam Undang-Undang Nomor 19 Tahun 2019 tentang Perubahan Kedua Undang-Undang Nomor 30 Tahun 2002 tentang Komisi Pemberantasan Korupsi, yang menyatakan: "Dalam melaksanakan tugas pencegahan sebagaimana dimaksud dalam Pasal 6 huruf d, Komisi

Pemberantasan Korupsi berwenang melaksanakan langkah atau upaya pencegahan sebagai berikut: c. menyelenggarakan program pendidikan antikorupsi pada setiap jenjang pendidikan."

Lebih lanjut dalam Pasal 3 Undang-Undang Nomor 87 Tahun 2017 tentang Penguatan Pendidikan Karakter menegaskan bahwa pendidikan karakter diimplementasikan dengan menerapkan nilai-nilai Pancasila dalam pendidikan karakter, terutama meliputi nilai-nilai religius, jujur, toleran, disiplin, 
bekerja keras, kreatif, mandiri, demokratis, rasa ingin tahu, semangat kebangsaan, cinta tanah air, menghargai prestasi, komunikatif, cinta damai, gemar membaca, peduli lingkungan, peduli sosial dan bertanggungjawab." Jika nilai-nilai tersebut kita hubungkan dengan nilainilai antikorupsi yakni: jujur, peduli, mandiri, disiplin, bertanggungjawab, kerja keras, sederhana, adil, dan kreatif, dan berani, maka dapat kita temukan persesuaiannya yakni pada nilai jujur, disiplin, kerja keras, mandiri, peduli dan bertanggungjawab. Maka, idealnya pendidikan antikorupsi dilakukan dengan memperkuat implementasi pendidikan karakter yang berpegang pada nilai-nilai Pancasila. Apabila peserta didik mampu menghayati serta mengamalkan nilai-nilai Pancasila secara otomatis ia telah terbentuk menjadi pribadi yang antikorupsi.

Pendidikan antikorupsi akan terimplementasikan secara optimal jika berorientasi pada pendidikan karakter yang dapat pula dikategorikan sebagai pendidikan nilai. Hal ini dikarenakan tujuan dari pendidikan antikorupsi sejatinya ialah membentengi anakanak/peserta didik dari perilaku koruptif. Secara nyata upaya untuk mencapai tujuan pendidikan antikorupsi dilakukan dengan memberikan bekal kepada peserta didik mengenai nilai-nilai luhur sebagaimana diajarkan di dalam pendidikan nilai.

Lebih lanjut di dalam Surat Edaran Menteri Dalam Negeri Nomor : 420/4047/SJ tentang Implementasi Pendidikan Karakter dan Budaya AntiKorupsi pada SatuanPendidikan, telah diuraikan mengenai pedoman implementasi pendidikan antikorupsi, yang secara garis besarnya adalah sebagai berikut:

A. Penguatan pendidikan karakter adalah langkah untuk memperkuat karakter pserta didik di bawah tanggung jawab satuan pendidikan melalui harmonisasi hati, rasa, pikir, dan olah raga sebagai bagian dari Gerakan Nasional Revolusi Mental (GNRM);

B. Penguatan pendidikan karakter dan kultur antikorupsi 


disesuaikan dengan kondisi
peserta didik berdasarkan jenjang
pendidikannya, dan dilaksanakan
dengan menerapkan nilai-nilai
pancasila dalam bentuk
pendidikan karakter terutama
meliputi nilai-nilai kejujuran,
tanggungjawab, kesederhanaan,
kepedulian, kemandirian, disiplin,
keadilan, kerja keras, dan
keberanian, dan dilaksanakan
degan menggukan prinsip dan
pendekatan;
Internalisasi nilai karakter dalam
proses belajar mengajar
dilaksanakan dengan cara sebagai
berikut:

1. Membuat tata kelola kelas dan metode bimbingan sesuai karakter peserta didik;

2. Mengembangkan kurikulum muatan lokal sesuai dengan kebutuhan, karakteristik daerah satuan pendidikan dan peserta didik.

D. Implementasi dari pendidikan karakter di sekolah dilaksanakan dengan pembiasaan nilai-nilai utama dalam keseharian sekolah dengan cara:

1. Membangun dan mematuhi norma, peraturan dan ketentuan-ketentuan sekolah dan;

2. Memperkuat peranan orang tua sebagai pemangku kepentingan utama pendidikan dan komite sekolah sebagai lembaga partisipasi masyarakat.

Berdasarkan surat edaran tersebut pelaksanaan pendidikan antikorupsi pada pendidikan formal dilaksanakan dengan mengajarkan pendidikan karakter. Pendidikan karakter dapat terimplementasi dengan optimal jika terwujud melalui terbentuknya budaya antikorupsi di lingkungan sekolah serta mendapatkan dukungan dari orang tua serta kontribusi dari masyarakat untuk mencapai tujuan pendidikan antikorupsi. 


\section{PENUTUP}

\section{A. Kesimpulan.}

Upaya pemberantasan korupsi tidak lagi dapat mengandalkan pada upaya represif yakni dengan menindak pelakunya, oleh karena korupsi telah menjalar ke seluruh institusi baik swasta maupun pemerintah. Pencegahan korupsi merupakan upaya yang ideal dan optimal dalam memberantas korupsi. Salah satu pencegahan yang efektif untuk memberantas korupsi adalah dengan memberikan pendidikan antikorupsi kepada pelajar mulai dari jenjang pendidikan sekolah dasar, sekolah menengah, hingga pendidikan tinggi. Jalur pendidikan formal dipiluh untuk menanamkan nilai-nilai antikorupsi oleh karena struktur dan wewenangnya terhadap penyelenggaraan pendidikan lebih sistematis dan memiliki otoritas dalam penyelenggaraan pendidikan.

Penyelenggaraan pendidikan antikorupsi kepada pelajar sekolah dasar dan sekolah menengah disesuaikan dengan kondisi peserta didik. Pengajaran pendidikan antikorupsi dilaksanakan dengan mengintegrasikan

pendidikan antikorupsi ke dalam kurikulum pembelajaran dan dilaksanakan dalam kegiatan kurikuler dan ekstrakulikuler. Pendidikan antikorupsi dilaksanakan dengan menanamkan nilai-nilai antikorupsi kepada siswa, dan dilanjutkan dengan diimplementasikan dalam beberapa kegiatan sebagai wujud nyata dari pendidikan antikorupsi, misalnya dengan pembiasaan dalam budaya perilaku antikorupsi di sekolah.

\section{B. Saran.}

Bagi tenaga pendidik: memberikan pendidikan antikorupsi kepada peserta didik dengan memperhatikan 3 (tiga) aspek pendidikan yakni: kognitif, afektif dan psikomotorik dengan berpedoman pada buku pedoman pendidikan antikorupsi KPK, dan peraturan perundang-undangan lainnya.

Bagi pemerintah, pemerintah daerah khususnya dinas pendidikan: mengawasi dan mengevaluasi implementasi pendidikan antikorupsi di setiap jenjang pendidikan formal, baik 
sekolah dasar maupun sekolah

menengah.

\section{DAFTAR PUSTAKA}

A. Buku.

Eddy O.S Hiariej, 2014, Prinpsip-Prinisip Hukum Pidana, Cahaya Atma Pustaka, Yogyakarta.

Eko Handoyo, 2013, Pendidikan Anti Korupsi, Penerbit Ombak, Yogykarta.

Karlina Helmanita dan Sukron Kamil, Pendidikan Antikorupsi di Perguruan Tinggi, CSRC UIN Syarif Hidayatullah, Jakarta.

Mukti Fajar dan Yulianto Achmad, 2009, Dualisme Peneltiian Hukum: Normatif dan Empiris, Pustaka Pelajar, Yogyakarta.

Muladi, 1995, Kapita Selekta Sistem Peradilan Pidana, Badan Penerbit Universitas

Diponegoro,

Semarang.

Peter Mahmud Marzuki, 2005, Penelitian Hukum: Edisi Revisi, Kencana Prenada Media Group, Jakarta.

Teguh Prasetyo dan Abdul Halim Barkatullah, 2012, Politik Hukum

C. Jurnal.

Slamet Tri Wahyudi, 2012, Problematika Penerapan Pidana Mati dalam Konteks Penegakan Hukum di Indonesia, Jurnal
Pidana: Kajian Kebijakan Kriminalisasi dan Dekriminalisasi, Pustaka Pelajar, Yogyakarta.

B. Peraturan Perundang-Undangan. Undang-Undang Dasar Negara Republik Indonesia Tahun 1945.

Undang-Undang Nomor 31 Tahun 1999 tentang Pemberantasan Tindak Pidana Korupsi.

Undang-Undang Nomor 20 Tahun 2001 tentang Perubahan atas UndangUndang Nomor 31 Tahun 1999 tentang Perubahan atas UndangUndang Nomor 31 Tahun 1999 tentang Pemberantasan Tindak Pidana Korupsi.

Undang-Undang Nomor 30 Tahun 2002 tentang Komisi Pemberantasan Korupsi sebagaimana dubah dalam Undang-Undang Nomor 19 Tahun 2019 tentang Perubahan Kedua atas Undang-Undang Nomor 30 Tahun 2002 tentang Komisi Pemberantasan Korupsi.

Undang-Undang Nomor 87 Tahun 2017 tentang Penguatan Pendidikan Karakter.

Hukum dan Peradilan, Volume 1, Nomor 2.

Totok Suyanto, 2005, Pendidikan Anti Korupsi dan Pengembangan 
Budaya Sekolah, Nomor 23, Edisi

XIII, JPIS.

D. Internet.

Kementerian PPN/Bappenas, 2018,

Pencegahan dan Pemberantasan

Korupsi dalam Konteks

Perencanaan Pembangunan:

Materi Perencanaan

Pembangunan Nasional,

disampaikan pada International

Bussines Integrity Conference

yang diselenggarakan, 4

Desember 2018,

https://www.kpk.go.id/images/ln

tegrito/2018/MateriHAKORDIA20

18/Pencegahan-dan-

Pemberantasan-Korupsi-dalam-

Konteks-Perencanaan-

Pembangunan-Menteri-

Perencanaan-pembangunan-

Nasional.pdf, diakses pada 27

September 2020 Pukul 06:37

WIB. 